\title{
Sports Reform Research based on Promoting the Physical Health of Students of Local Colleges and Universities
}

\author{
Song-wei Wu \\ Department of Physical Education \\ Hubei Engineering University \\ Xiaogan , China \\ wusongwei@126.com
}

\author{
Kai Zhou \\ Department of Physical Education \\ Hubei Engineering University \\ Xiaogan, China \\ wusongwei006@sohu.com
}

\begin{abstract}
To promote the physical health level of college students comprehensively is the key for improving the sports education quality in colleges and universities, as well as the starting point of our education. There are lots of research articles about it, but the study of local colleges and universities sports teaching reform is not too much. This paper mainly analyzes the characteristics and the student's physical conditions of students of local colleges and universities in China, and combined with the current status of local colleges and universities sports teaching reform in our country. This paper is aimed at giving some suggestions about the local colleges and universities sports reform in our country, and eventually strengthen local colleges and universities sports culture construction. At the same time, it can change the traditional sports concept and improve students' health within the power of self-training. Pay attention to the teaching of students' sports health knowledge and the cultivation of lifelong body-building skills; what's more, it can also strengthen the organization and management of the extracurricular sports activities and guide students to establish a correct view on sports. This electronic document is a "live" template. The various components of your paper [title, text, heads, etc.] are already defined on the style sheet, as illustrated by the portions given in this document.
\end{abstract}

Keywords- local colleges and universities; physical education ; sports; the teaching reform

\section{INTRODUCTION}

The health problem of local college and university students has drawn the attention of our nation. At present, the number of local undergraduate colleges and universities is the largest in the recruitment of students scale and the most talent training in our country, and it is also the largest part of the popularization of higher education in China[1] . With the further development of market economy in our country and the continuous deepening of the reform of school curriculum, and based on the service of local social and economic development goal. Local colleges and universities will develop more application technology talented person. However, during the rapid transition in local colleges, we found out that a lot of students' physical health in local colleges and universities are not optimistic, though our country's relevant departments have done a lot of work to improve students' physical health, but still appeared different degrees of downward trend in recent years, the trend of the decline is not only newly enrolled students downward trend year by year, but also the annual variation trend with a group of students. To a certain extent, it shows a decrease in the level of local colleges and universities student physical health by school sports teaching, sports environment, and many other factors.

Therefore, combining with the characteristics of local colleges and universities students to discuss factors of influencing the physical health of students and try to find out the main factors which influence the physical health of students of local institutions. On the basis of this, provide some suggestions about the local colleges and universities in our country's school sports reform. In order to promote the full implementation of quality education and do something for our nation to become a powerful human resources country in the world.

\section{LOCAL COLLEGES AND UNIVERSITIES STUDENT'S PHYSICAL HEALTH SITUATION}

Most of the local college and university students come from the countryside, there is a big difference of family conditions and living environment compared with the city ,so it leads to a different life habits and health awareness[2]. So on the basis of rural students' data and reference city students constitution's data, it can reflect the profile of local colleges and universities in our country college students' physical health.

\section{A. Local Colleges and Universities Student Physical and Health Status Has Improved}

From the ministry of education's "2010 National Student Physical and Health Research Results Announcement”, Local colleges and universities students morphological development levels was continue to improve, $19 \sim 22$ urban boys and girls, the rural boys and girls age height were averaged growth 0.84 , $0.55,1.34,0.64 \mathrm{~cm}$, weight were averaged growth $1.52,0.27$, 2.07, $0.27 \mathrm{~kg}$, chest circumference were averaged growth 0.63 , $0.29,0.97,0.43 \mathrm{~cm}$ (the ratio for 2005, the same below); Lung capacity level rise a turning point, city boys and girls, the rural boys and girls in $19 \sim 22$ year old age group were increased an average of 137, 102, 185, $123 \mathrm{ml}$. According to local colleges and universities student's data, we can find that their physical standards has a certain improvement. 


\section{B. There Are Some Problems About The Local College Students' Physical Health}

From the data above, we can easily find that there are still some problems in local college and university student's physical health: college students' physical quality continued to decrease, but it decreased very slowly, and the research results show that the 19-22 years old age group except ZuoWeiTi proneness indexes, explosive force, strength, endurance and other physical quality level fall further, but compared with the previous five years (2000-2005), decreased significantly. Poor vision detection rate continues to rise, according to the urban students is significantly higher than rural students; Students obesity status, urban students is significantly higher than rural students, but the overall obesity rates are rising. The living conditions of rural students and urban students life have certain gap, there will be naturally higher obesity rates, but in recent years, rural living conditions are improving, overall, local colleges and universities student's obesity rate is also rising.

\section{THE MAIN INFLUENCE FACTORS OF LOCAL COLLEGE STUDENT'S PHYSICAL HEALTH}

With the rapid development of economy, the increasingly fierce competition in society, colleges and universities after enrollment expansion of college students is growing rapidly. Relevant data show: the employment rate of local undergraduate colleges and universities is low, low rate of professional counterparts, the employment quality is not high, the 2011 employment rate is only $75.8 \%$, is the lowest three universities [3]. Effects of physical health level of college students by many factors, including living habits, eating habits, social interaction, biological genetic etc.. In addition, the employment pressure, the crisis of survival, academic predicament and psychological problems also caused a great influence to the students' body and mind. The following analysis and discussion of the factors affecting the students' physical health from three aspects.

\section{A. Social Influence Factors}

The influence of social factors on the constitution is the most easily overlooked as an important factor, but it is an objective existence[4]. The students are individuals in society, and it is the basic cell of the society, the quality of students' physical health in addition to genetic factors also affected by social factors. As everyone knows, leading to the formation of the reasons of College Students' physical health problems are perplexing social background. Therefore, to enhance the college students of local colleges and universities physical health is far from enough only relying on the school education intervention, it also rely on the education sector, the joint efforts of the whole society.

In the marketing economy background, eager for quick success and instant benefits are common social rows. Society pays little attention to the school sports facilities, sports activities area and honor. Coupled with the modern life rhythm is accelerated greatly to people's life, all kinds of unhealthy life style also influence students' physical health. According to the researchers, social factors influencing Chinese students' physical health are mainly in the following three aspects: first is influenced by traditional ideas, heavy wisdom light body thought accounted for the larger proportion; second is that the social development leads to the change of lifestyle, physical activity than in the past greatly reduced; third is that the employment of graduates is one-sided unit of assessment, pay attention to professional courses, foreign language and computer level, but to the condition of graduates of local universities physical health is of no or very little consideration.

\section{B. Family Factors}

It is well known that the family is the first school which training and teaching their children, it shouldering the important social function[5]. Family education affects children' growth and development in a very important degree. The impact of China's long-term exam oriented education system and the increasingly fierce competition for talent background, coupled with the traditional idea of "parents who hope their children could have a bright future", think that longer as the kids learning can be better. so that children from an early age was "forced" to accept a wide variety of extracurricular education and tuition, almost occupied the students all the spare time, the students grew up without the habit of exercise. After graduated from university, they will naturally also have no awareness of physical exercise, seriously affecting the health of students. Many rural children in school is just to learn, and go back home to help at home to do housework, farm etc.. In their growing environment inside, labor is exercise, they don't pay attention to sports, there is no exercise consciousness, it is very difficult to master one or two physical exercise skills. and to university, no farm work, nutrition can not keep up, coupled with lack of exercise consciousness, therefore their physical health status is very difficult to change.

\section{Personal Factors}

Internal cause is the driving force of development and changes of things, the student's own weak consciousness of physical exercise is the main cause of its physical deterioration. Personal lifestyle is the main cause of physical health level of happen to download, With the development of information technology, college students contact network is more and more long, Internet, play games, online chat, watch porn movies, pornographic books, watch TV, etc., In the process of this breed out some bad living habits, such as smoking, drinking, eating snacks, stay up late, online dating, play CARDS, sit for a long time, less time to exercise and other lifestyle, and it would do much to its adverse impact on physical health.

In addition, many college students from countryside to the cities to study at the beginning of access to a lot of different people and things, life habits are hard to adapt to come over, often feel lonely, even attacked by others, these will give their psychological impact, thus indirectly affect their physical health level. Plus a lot of local colleges and universities students lack of social experience and social communication narrowly, fewer contacts with classmates, friends, and gradually closed themselves, they often feel lonely and helpless; Some students sometimes against abuse, intimidation, harassment by the others, etc., also can give them the psychological impact of different level. In addition many research results show that insufficient physical activity is at present academia as the most important factor; Other unreasonable diet, excessive intake of calories, fat, some 
students for some college students lack of nutrition, weight loss are the cause of university, poor physical health.

\section{LOCAL COLLEGE AND UNIVERSITY SCHOOL SPORTS REFORM MEASURES}

School physical education is shouldering the sports fitness skills teaching, school physical education is the foundation of lifetime sports. Sports interest and habit is important to improve students' autonomous learning and lifelong insist on taking exercise, the premise of improve students' physical health is the foothold of the current school sports work, cultivate students' consciousness of lifetime sports is a home to return to the school sports work[6]. In order to achieve allround quality education, the sports quality of education should be strength, and to match with the requirements of the national students physical health level. So, based on the influence factors of local colleges and universities students physical health, the corresponding school sports reform, efforts to achieve school physical education to improve students' physical health level, to improve students' sports skills, develop healthy personality "trinity" goal.

\section{A. Strengthen Target Management, Strengthening the Position of the School Sports Work and the Students' Physical Health}

Improve the students' physical health monitoring system, to formulate the basic standard of higher school sports work and supporting measures for its implementation. Organize the formulation of the annual report and publish the school sports work each year. Start the student movement skill evaluation standard research, and students physical health test of synchronization for physical health supervision platform. School physical education in training students' will to bear hardships and stand hard work quality, teach students scientific exercise methods, training students' lifelong physical exercise habit has an irreplaceable role. Therefore, according to the actual situation of local institutions also take reasonable measures to comprehensively promote the improvement of the local colleges and universities student physique, comprehensively promote quality education of our country.

\section{B. Strengthen the Physical Education and Extracurricular Exercise, Prosper Campus Sports Culture}

The student schoolwork burden overweight, lack of exercise is a major cause of the students' physical health decline, and the real cause is the comprehensive results of the factors of society, school, family and students.. We will further improve the local colleges and universities sports curriculum plan in the integration of sports venues, such as sports resources and professional personnel on the basis of extracurricular time, actively organize students to carry out sports cultural activities. Campus sports culture is to promote students' physical health and the main factors of sports development, develop good lifestyle, actively build the campus sports culture atmosphere, set up the health first education guiding ideology. Makes the majority of students take sports culture into the inner force of the students' consciousness of fitness and exercise science, make students establish the correct concept of sports.
"School Sports Teaching Reform Project" is to develop physical education rely on "Basis of Exercise and Sports" measures, and set up the teaching reform of physical education and sports union, vigorously promote the athletics, football, basketball, volleyball, swimming, martial arts, gymnastics and other sports, improve the teaching quality and students' movement skills. Another implementation of the "School Sports Teachers' Professional Practice Ability Promotion Project". Engaged in the development of sports skill standards for physical education teachers. The implementation of special part-time physical education teachers training system, gradually increase and the ability of different sports teaching basic skills and popularity of sports teacher's professional capacities.

\section{Set Up a Diversified School Physical Education Course Content to Satisfy the Demands Of Different Students}

Many local colleges and universities in offering sports course always face the widespread problem that too many students in one class, the teaching contents of the course is too simple. For physical education teaching, small class teaching is one of the many domestic experts and scholars advocated the teaching means, but for the local colleges and universities is not practical, often around each sports classes are generally 30 - 40 people. For students, many students take physical education curriculum teaching as entertainment time, more drama in physical education class indifference. In addition to the venue, funding constraints many emerging sports items can not be carried out, this also makes some students lose interest in learning.

\section{Relevant Social Departments Should Work Together to Create a Good Environment For Sports Teaching}

Physical health problems of students in our country has become the question which the society cares together and takes seriously, such as society, education and sports departments need to actively support each other, work together to form resultant force, strengthen the construction of campus sports culture, realize the benign intervention on physical health of students. Suggest to learn sports as a focal point of the national fitness in technology, personnel, facilities and sports organization construction intensify support. And then to strengthen the supervision of the school sports, school sports work rewards and punishment mechanism. Strictly carry out the education supervision regulations, the establishment of physical health of students and the system of school physical education work. Units which have made outstanding achievements in their work relating to sports shall be commended or awarded in accordance with the relevant regulations.

\section{CONCLUSION}

To ensure the physical and mental health of teenagers in our country is necessary and it will benefit a lot to our nation in many aspects. Strengthen the school sports, enhance physical human resource power, shouldering the construction of students and meet the needs of the masses to accept good education. Local colleges and universities student physical health education system, curriculum design, mass sports activities, sports equipment and etc. Various factors influence 
the results of the students themselves. Therefore we should promote and develop to adapt to the physical and psychological characteristics of students sports activities actively, increase input in the construction of school physical education funds and the proportion of school sports infrastructure, strengthen the cognitive education on college students healthy way of life, and create a good atmosphere of physical culture, make them active and reasonable use of leisure time, develop a healthy, civilized, scientific sports life style.

\section{REFERENCES}

[1] DENG Xue-ping, SUN Yan-fang, SUN Min, et al. Hubei province of local college students' physique present situation and countermeasure research[J]. Career Horizon, 2013, 9(7): 141-144.

[2] ZHANG Xiang-qun, GONG Xing-man. Research on physical education curriculum reform of local colleges in Guangdong[J]. Bulletin of Sport Science \& Technology, 2011, 19(11): 58-60.

[3] ZHANG Fei. Analysis on sports reform of higher vocational college[J]. Bulletin of Sport Science \& Technology, 2010, 18(2): 67-68.

[4] LIU Yan. Reform of college physical education from Physical-Sociology angle[J]. Sichuan Sports Science, 2006(1): 125-127,13.

[5] HAO Jian-feng, WANG Wen-qing, WANG Jing. The practice and research of deepen physical education reform under the background of sunshine sports[J]. Bulletin of Sport Science \& Technology, 2013, 21(3): $10-12$.

[6] WU Shao-yi, WANG Rui. Students' mental health factors and personality factors related to research[J]. Joumal of Shandong Youth Administrative Cadres College, 2009( 04): 48- 52. 